Volume 3 Nomor 2, Agustus 2018, halaman 171-180

\title{
EFEKTIVITAS PENGGUNAAN MODEL PEMBELAJARAN KOOPERATIF TIPE THINK TALK WRITE UNTUK MENINGKATKAN KEAKTIFAN DAN HASIL BELAJAR MATEMATIKA SISWA MATERI LOGARITMA
}

\author{
THE EFFECTIVENESS OF THINK TALK WRITE TYPE \\ COOPERATIVE LEARNING MODEL TO IMPROVE STUDENTS' \\ ACTIVENESS AND LOGARITHM LEARNING OUTCOMES
}

\author{
Panji Ibnu Prasetia ${ }^{1}$, Farid Gunadi ${ }^{2}$, Fiqriyah ${ }^{3}$ \\ ${ }^{1}$ SMA Negeri 1 Sindang, J1. Letjen. MT. Haryono Sidang Indramayu 45222, \\ panjiibnuprasetia@gmail.com \\ ${ }^{2,3}$ Universitas Wiralodra, Jl. Ir. H. Djuanda KM.3 Indramayu 45213, \\ faridgunadi@unwir.ac.id, fikriyah26@gmail.com
}

\begin{abstract}
ABSTRAK
Penelitian ini bertujuan untuk mengetahui efektivitas model pembelajaran kooperatif tipe Think Talk Write (TTW) untuk meningkatkan keaktifan dan hasil belajar siswa pada materi logaritma. Penelitian ini merupakan Penelitian Tindakan Kelas (PTK) yang dilakukan di SMA Negeri 1 Sindang. Teknik pengumpulan data yang digunakan antara lain teknik observasi dan tes. Subjek dalam penelitian ini adalah siswa kelas X-8 MIPA yang berjumlah 36 siswa. Dalam penelitian ini, untuk menganalisis data digunakan uji t satu sampel. Hasil pengolahan data hasil belajar diperoleh rata-rata siklus I sebesar 78,73, siklus II 84,17 dan siklus III 86,80. Begitu juga dari peningkatan jumlah siswa yang mencapai ketuntasan belajar yaitu dari siklus I sebanyak 18 dari 30 siswa atau 60\% dengan kriteria ketuntasan tinggi, siklus II 23 dari 30 siswa atau 76,67\% kriteria ketuntasan tinggi, dan siklus III 25 dari 30 siswa atau 83,33\% termasuk kategori kriteria ketuntasan sangat tinggi. Hasil uji efektivitas yang diperoleh pada siklus I, siklus II dan siklus III $t_{\mathrm{o}}>t_{(0,05,30)}$ efektif. Sedangkan hasil pengolahan data keaktifan yang diperoleh mengalami peningkatan pada setiap siklus dengan rata-rata siklus I 46,67\%, siklus II 73,33\%, dan siklus III 90\%.
\end{abstract}

Kata Kunci: Model Pembelajaran Kooperatif Tipe TTW, Keaktifan, Hasil Belajar Logaritma

\section{ABSTRACT}

This study aims to investigate the effectiveness of Think Talk Write (TTW) type cooperative learning model to improve students' activeness and logarithm learning outcomes. This research is a Classroom Action Research conducted in SMA Negeri 1 Sindang. The data collection techniques used were observation and test techniques. The subjects in this study were 36 students of X-8 MIPA. In this research, one sample t-test was used to analyze the data. The Result of learning outcomes data processing, the average in first cycle is 78,73 , in the second cycle is 84,17 , and the third cycle is 86,80. Likewise from the improvement of the students' number who achieved learning completion from the first cycle is 18 students of 30 students or $60 \%$ with high completion criteria, the second cycle is 23 students of 30 students or 76,67\% with the high completion criteria and the third cycle is 25 students of 30 students or 83,33\% means that it is included into highest completion criteria category. The results of effectiveness test obtained in first cycle, second cycle and third cycle $t_{o}>t_{(0,05,30)}$ are effective. While the results of activeness data processing that has been 
obtained are improved in every cycle with 46,67\% average in the first cycle, 73,33\% in the second cycle, and $90 \%$ in the third cycle.

Keywords: TTW Type of Cooperative Learning Model, Activeness, Logarithm Learning Outcomes

\section{How to Cite: Prasetia, P. I., Gunadi, F., \& Fiqriyah. (2018). Efektivitas Penggunaan Model Pembelajaran Kooperatif Tipe Think Talk Write untuk Meningkatkan Keaktifan dan Hasil Belajar Matematika Siswa Materi Logaritma. Mathline: Jurnal Matematika dan Pendidikan Matematika, Vol.3, No.2, 171-180.}

\section{PENDAHULUAN}

Kualitas pendidikan di suatu negara dapat dilihat dari proses pembelajaran di sekolah, di mana pembelajaran yang bertujuan untuk mempersiapkan peserta didik menghadapi perubahan dunia dengan menekankan pada penalaran logis, rasional, dan kritis, serta memberikan ketrampilan kepada mereka untuk mampu mengaplikasikan pembelajaran, yang didapatkan di sekolah khususnya pembelajaran matematika. Matematika merupakan mata pelajaran yang wajib dipelajari karena matematika merupakan ilmu universal yang mendasari segala ilmu, mempunyai peran penting dalam berbagai disiplin ilmu dan memajukan daya pikir manusia Menurut Supartono (Misdalina \& Purwoko, 2009) menyatakan bahwa kenyataan yang masih sering ditemui adalah masih banyak siswa yang mengalami kesulitan dalam mempelajari matematika. Beberapa penyebab kesulitan tersebut antara lain pelajaran matematika tidak tampak kaitannya dengan kehidupan sehari-hari, cara penyajian pelajaran matematika yang monoton dari konsep abstrak menuju ke konkrit, tidak membuat anak senang belajar.

Hendriana \& Sumarmo (2017) menyatakan pendidikan matematika di tanah air saat ini sedang mengalami perubahan paradigma. Terdapat kesadaran yang kuat, terutama dikalangan pengambil kebijakan, untuk memperbarui pendidikan matematika. Salah satu kecakapan atau kemahiran matematika yang diharapkan dapat tercapai dalam belajar matematika mulai dari SD/MI hingga SMA/MA adalah menunjukkan pemahaman konsep matematika yang dipelajari, menjelaskan keterkaitan antar konsep dan mengaplikasikan konsep atau algoritma, secara luwes, akurat, efisien, dan tepat, dalam pemecahan masalah. Dalam kecakapan ini, tampak bahwa setelah siswa mendapatkan pembelajaran, siswa diharapkan mampu menerapkan ide-ide matematika untuk memperoleh pengalaman menggunakan pengetahuan serta keterampilan yang sudah dimilikinya dengan cara membuat keterkaitan antar konsep, baik antar konsep dalam matematika itu sendiri 
maupun relevansi konsep matematika dengan bidang lain dan dengan permasalahan seharihari.

Berdasarkan hasil observasi dengan Bapak Panji Ibnu Prasetya, S. Pd. selaku guru matematika kelas X SMA Negeri 1 Sindang, siswa kelas X mengalami kesulitan dalam mempelajari materi logaritma, terutama pada bagian grafik fungsi dan pertidaksamaan logaritma. Kemampuan memahami siswa dalam menyelesaikan masalah fungsi logaritma dan pertidaksamaan logaritma masih rendah.

Dari hasil diskusi dan pengamatan peneliti bersama guru pengamat dapatlah diungkap permasalahan yang terjadi dalam proses pembelajaran yaitu: (a) penyajian pembelajaran matematika yang monoton; (b) motivasi belajar siswa masih rendah; (c) tingkat kecerdasan siswa yang masih rendah, (d) siswa kurang aktif dalam pembelajaran matematika; (e)t ingkat keberhasilan pembelajaran matematika masih rendah; (f) Guru masih menggunakan metode pembelajaran yang monoton dan hanya berpusat pada guru sehingga siswa tidak dapat mengembangkan kemampuannya; (g) model pembelajaran yang digunakan kurang inovatif dan kreatif. Menurut Sardiman (2014) mengatakan bahwa, "guru tidak semata-mata sebagai "pengajar" yang melakukan transfer of knowledge, tetapi juga sebagai "pendidik" yang melakukan transfer of values dan "pembimbing" yang memberikan pengarahan dan menuntun siswa dalam belajar". Guru sebagai salah satu unsur dalam proses belajar mengajar memiliki peran yang penting yaitu sebagai pengajar yang melakukan transfer of knowledge dan sebagai pembimbing yang mendorong potensi siswa dalam belajar. Maka akan berpengaruh langsung terhadap hasil belajar matematika. Oleh karena itu usaha meningkatkan hasil belajar matematika dapat dilakukan salah satunya dengan memperbaiki model pembelajaran.

Model pembelajaran merupakan komponen yang penting dalam menentukan hasil belajar siswa karena pembelajaran merupakan suatu sistem yang terdiri atas berbagai komponen yang saling berhubungan satu dengan yang lain. Komponen tersebut meliputi: tujuan, materi, metode dan evaluasi. Keempat komponen pembelajaran tersebut harus diperhatikan oleh guru dalam memilih dan menentukan model-model pembelajaran apa yang digunakan dalam kegiatan pembelajaran, Rusman (2016). Pembelajaran konvensional mulai banyak tak digunakan, karena pada pembelajaran konvensional siswa diperlakukan sebagai objek semata. Siswa dipandang pasif, tidak dapat aktif menyampaikan pendapatnya.

Selain model pembelajaran yang inovatif dan kreatif, keaktifan belajar juga sangat penting bagi keberhasilan proses pembelajaran. Keberhasilan guru dalam mengefektifkan 
siswanya mengikuti proses pembelajaran dapat dilihat dari perubahan perilaku siswa dan rasa tertarik untuk mengikuti pembelajaran yang disampaikan oleh guru. Menurut Sardiman (2014) mentakan bahwa, "Keaktifan adalah kegiatan yang bersifat fisik maupun mental, yaitu berbuat dan berfikir sebagai suatu rangkaian yang tidak dapat dipisahkan".

Salah satu model pembelajaran yang dapat mengaktifkan siswa adalah model pembelajaran kooperatif, karena guru perlu menerapkan suatu model pembelajaran yang melibatkan siswa dalam proses pembelajarannya dalam situasi ini siswa berperan aktif dalam menyelesaikan masalah. Model pembelajaran matematika yang dipilih pada penelitian ini adalah model pembelajaran think talk write. Menurut Suningsih, dkk. (2014), "Prestasi belajar matematika siswa yang menggunakan model pembelajaran kooperati tipe $T T W$ lebih baik dari pada menggunakan model pembelajaran konvensional”.

\section{METODE PENELITIAN}

Penelitian ini merupakan Penelitian Tindakan Kelas (PTK) yang dilakukan di SMA Negeri 1 Sindang tahun pelajaran 2017/2018. Subjek dalam penelitian ini adalah siswa kelas X-8 MIPA yang berjumlah 36 siswa. Variabel yang diamati dalam penelitian ini adalah keaktifan dan hasil belajar. Teknik penelitian yang digunakan yaitu pengamatan dan tes tertulis. Perencanaan penelitian terdiri dari 3 siklus, dan setiap siklus terdiri dari 4 tahap yaitu perencanaan (planning), pelaksanaan (action), pengamatan (observation), refleksi (reflection). Dalam penelitian ini, untuk menganalisis efektivitas pembelajaran digunakan prasyarat uji normalitas liliefors dan uji t satu sampel.

\section{HASIL DAN PEMBAHASAN}

Berdasarkan hasil pengolahan data hasil tes yang dilakukan tiap akhir siklus, diperoleh analisis data sebagai berikut.

Tabel 1. Hasil Uji Normalitas

\begin{tabular}{cccc}
\hline Siklus & Lo & $\mathbf{L}_{(\mathbf{0}, \mathbf{0 5} ; \mathbf{3 0})}$ & Keterangan \\
\hline I & 0,112 & 0,158 & Berdistribusi Normal \\
II & 0,092 & 0,158 & Berdistribusi Normal \\
III & 0,108 & 0,158 & Berdistribusi Normal \\
\hline
\end{tabular}

Berdasarkan tabel 1, menunjukkan bahwa pada siklus I diperoleh $\mathrm{L}_{\mathrm{o}}=0,112$ dan $\mathrm{L}_{(0,05,38)}=0,158$, pada siklus II diperoleh $\mathrm{L}_{\mathrm{o}}=0,092$ dan $\mathrm{L}_{(0,05,38)}=0,158$, pada siklus III diperoleh $\mathrm{L}_{\mathrm{o}}=0,108$ dan $\mathrm{L}_{(0,05,38)}=0,158$. Dengan taraf signifikansi $(\alpha)=0,05$, karena $\mathrm{L}_{\mathrm{o}}<\mathrm{L}_{\mathrm{k}}$, gagal menolak/ menerima $\mathrm{H}_{\mathrm{o}}$. Artinya sampel berasal dari populasi yang 
berdistribusi normal. Karena uji normalitas terpenuhi, maka selanjutnya adalah uji-t satu sampel.

Tabel 2. Hasil Uji t Satu Sampel

\begin{tabular}{ccccc}
\hline Siklus & Rataan & Varians & To & Tk \\
\hline I & 78,73 & 11,03 & 1,86 & 1,70 \\
II & 84,17 & 11,89 & 4,23 & 1,70 \\
III & 86,80 & 10,57 & 6,11 & 1,70 \\
\hline
\end{tabular}

Berdasarkan tabel 2, dengan taraf signifikasi $(\alpha)=0,05$, diperoleh pada siklus I $t_{\mathrm{o}}=$ 1,86 dan $t_{(0,05,30)}=1,70$; pada siklus II $t_{\mathrm{o}}=4,23$ dan $t_{(0,05,30)}=1,70$, dan pada siklus III $t_{\mathrm{o}}=$ 6,11 dan $t_{(0,05,38)}=1,70$. Pada siklus I siklus II dan siklus III $t_{\mathrm{o}}>t_{(0,05,38)}$ maka $\mathrm{H}_{\mathrm{o}}$ ditolak, artinya hasil penelitian pada siklus I,siklus II dan siklus III model pembelajaran kooperatif tipe Think Talk Write (TTW) efektif untuk meningkatkan hasil belajar matematika materi logaritma. Untuk perhitungan selengkapnya dapat dilihat pada lampiran. Dari data hasil tes yang dilakukan tiap akhir siklus, dilakukan pula analisis pencapaian ketuntasan belajar. Tingkat ketuntasan belajar disajikan dalam tabel 3 dan gambar 1 berikut.

Tabel 3. Ketuntasan Belajar

\begin{tabular}{cccc}
\hline \multirow{2}{*}{ Keterangan } & \multicolumn{3}{c}{ Nilai Tes Siswa pada Siklus } \\
& I & II & III \\
\hline Rata-rata & 78,73 & 84,17 & 86,80 \\
Persentase Ketuntasan & $60 \%$ & $76,67 \%$ & $83,33 \%$ \\
\hline
\end{tabular}

Ketuntasan belajar yang disajikan dalam tabel memperlihatkan bahwa rata-rata skor tes siswa pada siklus I sebesar 78,73, dengan jumlah siswa tuntas belajar pada siklus I sebanyak 18 dari 30 siswa yang mengikuti tes pada siklus I. Jadi presentase siswa yang tuntas belajarnya adalah 60\%. Dari hasil tersebut kriteria tingkat keberhasilan belajar pada siklus I termasuk dalam kriteria tinggi.Rata-rata skor tes siswa pada siklus sebesar 84,17 dan jumlah siswa yang tuntas pada pembelajaran di siklus II sebanyak 23 dari 30 yang mengikuti tes pada siklus II. Sehingga presentase ketuntasan belajarnya adalah $76,67 \%$.

Dari hasil tersebut kriteria tingkat keberhasilan belajar pada siklus II termasuk dalam kriteria tinggi. Sedangkan rata-rata skor tes siswa pada siklus III sebesar 86,80 dengan jumlah siswa yang tuntas pada pembelajaran di siklus III sebanyak 25 dari 30 yang mengikuti tes pada siklus sehingga presentase ketuntasan belajarnya adalah 
83,33\%. Dari hasil tersebut kriteria tingkat keberhasilan belajar pada siklus III termasuk dalam kriteria sangat tinggi. Selain pengolahan data, pelaksanaan pembelajaran juga perlu adanya penilaian dan pengamatan. Pelaksanaan pembelajaran ini di amati oleh 2 observer. Pada tahap pelaksanaan terlihat dari hasil observasi yang dinilai oleh observer, aktifitas guru pada siklus I belum mencapai hasil yang baik, hal tersebut dikarenakan tahap perkenalan atau adaptasi antara guru dan siswa dengan model pembelajaran.

Adapun permasalahan pada siklus I yang ditemukan oleh observer 1 dan observer 2 yaitu:

\begin{tabular}{|c|c|c|}
\hline No. & Observer I & Observer II \\
\hline 1. & $\begin{array}{l}\text { Tidak ada pengantar antara materi } \\
\text { dengan sub materi }\end{array}$ & $\begin{array}{l}\text { Kurang memperhatikan siswa pada } \\
\text { saat pembahasan materi }\end{array}$ \\
\hline 2. & $\begin{array}{l}\text { Motivasi pembelajaran tentang materi } \\
\text { pemfaktoran dalam kehidupan sehari- } \\
\text { hari kurang }\end{array}$ & $\begin{array}{l}\text { Semakin banyak jumlah siswa } \\
\text { dalam kelompok maka semakin } \\
\text { besar kemungkinan ada beberapa } \\
\text { siswa yang kurang aktif dalam } \\
\text { kelompok }\end{array}$ \\
\hline 3. & $\begin{array}{l}\text { Tidak disimpulkan sifat-sifat grafik } \\
\text { logaritma }\end{array}$ & $\begin{array}{l}\text { Belum Terasa TTW, hanya nampak } \\
\text { seperti biasa }\end{array}$ \\
\hline 4. & $\begin{array}{l}\text { Tidak dijelaskan komponen-komponen } \\
\text { grafik fungsi logaritma, seperti domain, } \\
\text { kodomain dan range. }\end{array}$ & $\begin{array}{l}\text { Dalam pelaksanaan Post test masih } \\
\text { ada beberapa siswa yang berdiskusi }\end{array}$ \\
\hline 5. & $\begin{array}{l}\text { Pemberian nilai contoh penggunaan } x \\
\text { hanya sebatas } x \geq 1\end{array}$ & \\
\hline
\end{tabular}

Dari hasil pengamatan terhadap siswa pada siklus I yang telah diberikan tindakantindakan pada instrumen keaktifan pada umumnya telah mencapai kategori aktif (A) yaitu dengan rata-rata 2,76>2,75 dari 30 siswa yang mengikuti pembelajara pada siklusI, yang inyatakan tidak aktif sebanyak 16 siswa dan yang aktif sebanyak 14 siswa atau 46,67\%, karena target keaktifan $75 \%$ maka siklus I belum mencapai kategori aktif. Dari hasil refleksi yang dilakukan peneliti dan observer, maka upaya yang harus diperbaiki pada tindakan siklus ke II menurut observer 1 dan 2 yaitu: 


\begin{tabular}{|c|c|c|}
\hline No. & Observer I & Observer II \\
\hline 1. & $\begin{array}{l}\text { Guru memberikan apersepsi dengan } \\
\text { baik }\end{array}$ & $\begin{array}{l}\text { Pandangan guru harus bisa meluas } \\
\text { memperhatikan siswa }\end{array}$ \\
\hline 2. & $\begin{array}{l}\text { Tambahkan tentang materi pemfaktoran } \\
\text { dalam kehidupan sehari-hari kurang }\end{array}$ & $\begin{array}{l}\text { Efesienkan jumlah siswa dalam } \\
\text { kelompok }\end{array}$ \\
\hline 3. & Diberikan sifat-sifat grafik logaritma & $\begin{array}{l}\text { Guru harus menguasi metode yang } \\
\text { digunakan }\end{array}$ \\
\hline 4. & $\begin{array}{l}\text { Harap dijelaskan tentang komponen- } \\
\text { komponen grafik fungsi logaritma, } \\
\text { seperti domain, kodomain dan range. }\end{array}$ & $\begin{array}{l}\text { Guru harus memberikan motivasi } \\
\text { lain dalam pembelajaran }\end{array}$ \\
\hline 5. & $\begin{array}{l}\text { Berikan contoh lain contoh penggunaan } \\
x \text {, tidak hanya sebatas } x \geq 1\end{array}$ & \\
\hline
\end{tabular}

Pada tahap pelaksanaan siklus II terlihat dari hasil observasi yang dinilai oleh observer, aktifitas guru pada siklus II terdapat peningkatan, tapi belum mencapai hasil yang sempurna, hal tersebut terjadi dikarenakan guru lebih memperhatikan dan memperbaiki masalah-masalah dalam hasil refleksi yang terjadi pada siklus I. Adapun permasalahan yang ditemukan oleh Observer I dan II adalah sebagai berikut.

\begin{tabular}{cll}
\hline No. & \multicolumn{1}{c}{ Observer I } & \multicolumn{1}{c}{ Observer II } \\
\hline 1. & $\begin{array}{l}\text { Dalam tahap "think” peneliti tidak } \\
\text { memberi batasan waktu }\end{array}$ & Siswa kurang kondusif saat bertanya \\
& & \\
& & Siswa kurang minat untuk \\
2. & Pada tahap talk terlihat keadaan kelas & mengerjakan soal didepan kelas dan \\
& kelas & pengawasan yang lemah pada saat \\
&
\end{tabular}

Dari hasil pengamatan terhadap siswa pada siklus II yang telah diberikan tindakantindakan pada instrumen keaktifan pada umumnya terjadi peningkatan dari siklus I untuk mencapai kategori aktif (A) yaitu rata-rata 3,00> 2,75, dari 30 siswa yang mengikuti pembelajaran pada siklus II, yang dinyatakan tidak aktif sebanyak 8 siswa dan yang aktif 
sebanyak 22 siswa atau 73,33\% karena target keaktifan 75\% maka siklus II belum mencapai kategori aktif.

Aktifitas pada siklus II lebih baik dibandingkan dengan siklus I. Walaupun ada beberapa hal yang harus diperhatikan demi pembelajaran selanjutnya. Dari hasil refleksi yang dilakukan peneliti dan observer, maka upaya yang harus diperbaiki pada tindakan siklus ke III menurut observer I dan II adalah sebagai berikut

\begin{tabular}{lll}
\hline No. & \multicolumn{1}{c}{ Observer I } & \multicolumn{1}{c}{ Observer II } \\
\hline & $\begin{array}{l}\text { Sudah cukup baik, jika dibandingkan } \\
\text { dengan siklus I, skenario pembelajaran } \\
\text { sudah dilaksankan sesuai RPP, tetapi } \\
\text { perlu ada perbaikan diantaranya dalam } \\
\text { mengkondisikan siswa pada beberapa }\end{array}$ & $\begin{array}{l}\text { Guru memberikan motivasi dalam } \\
\text { pembelajaran }\end{array}$ \\
& sesi. \\
& Kelas terlihat kurang kondusif, peneliti & Perketat lagi pengawasan terhadap \\
& diharapkan memberikan umpan balik & siswa beri tindakan tegas pada siswa \\
berupa pertanyaan-pertanyaan agar & yang kurang patuh \\
& terjadi penguatan konsep pada siswa & \\
\hline
\end{tabular}

Pada tahap pelaksanaan terlihat hasil observasi yang dinilai oleh observer, aktifitas guru pada siklus III terdapat peningkatan dari yang sebelumnya, meski belum mencapai hasil yang sempurna, hal tersebut terjadi dikarenakan guru lebih memperhatikan dan memperbaiki masalah-masalah dalam hasil refleksi yang terjadi pada siklus II maupun masalah-masalah yang belum terselesaikan pada siklus II. Adapun permasalahan yang ditemukan oleh observer I dan II pada siklus III adalah sebagai berikut.

\begin{tabular}{|c|c|c|}
\hline No. & Observer I & Observer II \\
\hline 1. & $\begin{array}{l}\text { Pembelajaran kooperatif kurang } \\
\text { inovatif }\end{array}$ & Tata letak tulisan yang belum sesuai \\
\hline 2. & $\begin{array}{l}\text { Soal dalam kelompok berbeda-beda, } \\
\text { siswa disibukan dengan soalnya } \\
\text { masing-masing tidak terlihat } \\
\text { kooperatifnya }\end{array}$ & $\begin{array}{l}\text { Perhatian siswa masih belum semua } \\
\text { memperhatikan }\end{array}$ \\
\hline
\end{tabular}


Dari hasil pengamatan terhadap siswa pada siklus III yang telah diberikan tindakantindakan pada instrumen keaktifan pada umumnya juga terjadi peningkatan untuk mencapai katagori aktif (A) yaitu rata-rata 3,01 > 2,75, dari 30 siswa yang mengikuti pembelajaran pada siklus II, yang dinyatakan tidak aktif sebanyak 3 siswa dan yang aktif sebanyak 27 siswa atau 90\% karena target keaktifan 75\% maka siklus III mencapai kategori aktif.

Aktivitas pada tindakan siklus III lebih baik dibandingkan dengan siklus II. Walaupun ada hal-hal yang harus diperhatikan demi pembelajaran selanjutnya. Dari hasil refleksi yang dilakukan peneliti dan observer, maka upaya yang harus diperbaiki pada penelitian atau pembelajaran berikutnya menurut observer I dan II adalah sebagai berikut.

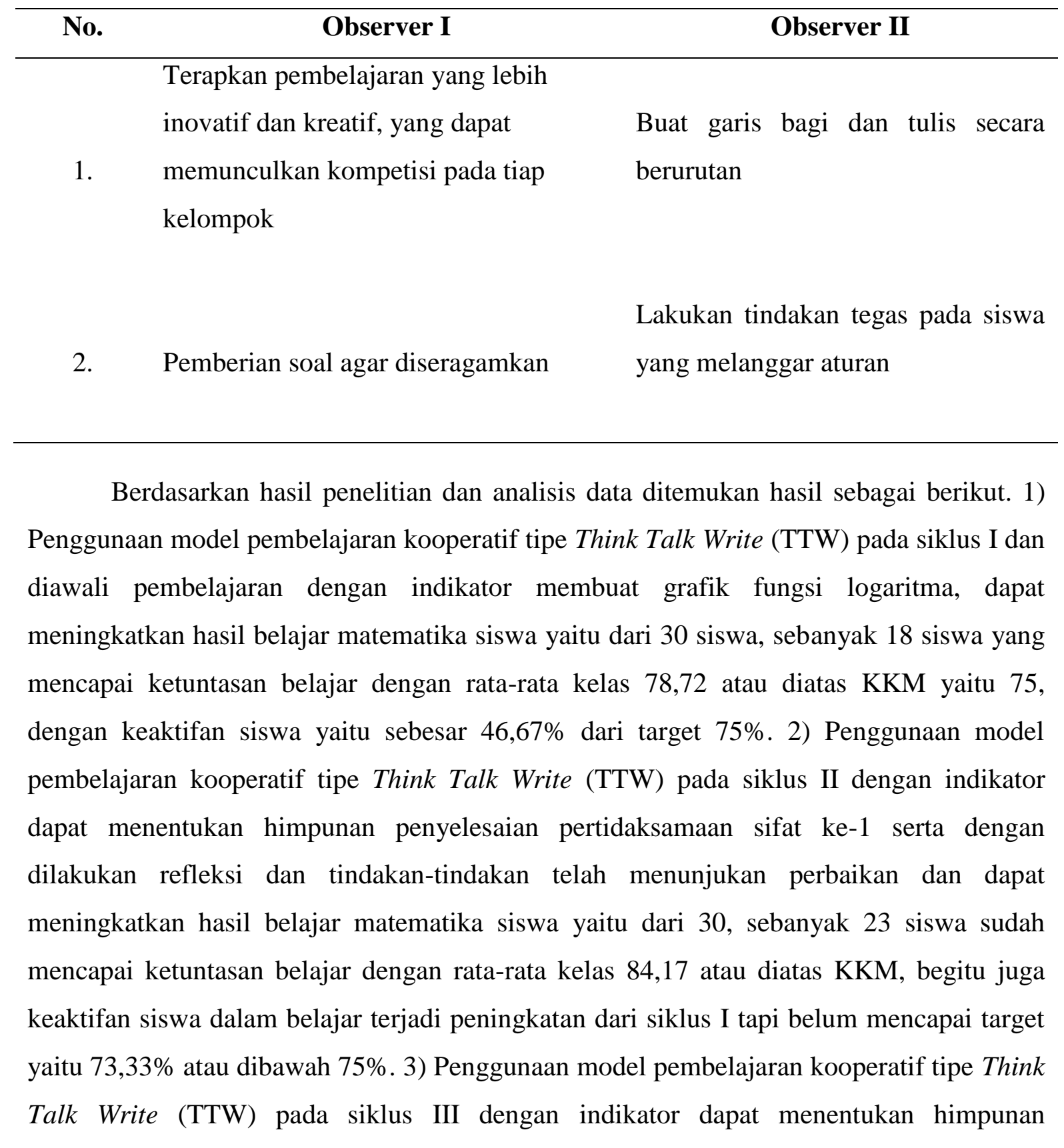


penyelesaian pertidaksamaan sifat ke-2 serta dengan dilakukan refleksi dan tindakantindakan telah menunjukan perbaikan dari pada siklus II hasil ini dapat dilihat dari meningkatnya hasil belajar matematika siswa yaitu dari 30 siswa, sebanyak 25 siswa sudah mencapai ketuntasan belajar dengan rata-rata kelas 86,80 atau diatas KKM, begitu juga keaktifan siswa dalam belajar terjadi peningkatan yaitu 90\% atau diatas 75\%. 4) Penggunaan model pembelajaran kooperatif tipe Think Talk Write (TTW) pada siklus I sampai dengan siklus III menunjukkan efektifitasnya dan benar bahwa penggunaan model pembelejaran kooperatif tipe think talk write dapat meningkatkan keaktifan dan hasil belajar matematika materi logaritma..

\section{KESIMPULAN}

Berdasarkan hasil pengamatan dan hasil pengolahan data selama penelitian yang meliputi analisis data untuk mengetahui peningkatan hasil belajar matematika siswa dan analisis observasi untuk mengetahui aktivitas siswa, maka diperoleh kesimpulan sebagai berikut. 1) Penggunaan model pembelajaran kooperatif tipe Think Talk Write (TTW) dapat meningkatkan keaktifan siswa dalam pembelajaran, 2) Penggunaan model pembelajaran kooperatif tipe Think Talk Write (TTW) dapat meningkatkan hasil belajar matematika siswa melalui tes pada setiap akir siklus (post test).

Berdasarkan hasil pengamatan, temuan dan refleksi. Maka saran itu guru yaitu dalam kurikulum yang berlaku saat ini diharapkan dapat menerapkan variasi model pembelajaran yang dapat meningkatkan keaktifan dan keterampilan dalam proses pembelajarannya, slaj satu alternatif model yang disarankan adalah model pembelajaran kooperatif tipe Think Talk Write (TTW). Sedangkan saran bagi peneliti selanjutnya bisa menambahkan waktu penelitian dan obyek penelitian yang lebih relevan.

\section{DAFTAR PUSTAKA}

Hendriana, H \& Sumarmo, U. (2017). Penilaian Pembelajaran Matematika. Bandung: Refika Aditama.

Misdalina, Z., \& Purwoko. (2009). Pengembangan Materi Integral untu Sekolah Menengah Atas (SMA) Menggunakan Pedekatan Pendidikan Matemtika Realistik Indonesia (PMRI) di Palembang. Jurnal Pendidikan Matematika, 3(1), 61-74.

Rusman. (2016). Model-Model Pembelajaran. Jakarta: Raja Grafindo Persada.

Sardiman A.M. (2014). Interaksi dan Motivasi Belajar Mengajar. Jakarta: PT Raja Grafindo Persada.

Suningsih, A., Kusmayadi, T. A., \& Riyadi, R. (2014). Eksperimentasi Model Pembelajaran Kooperatif Tipe TTW dan TPS Pada Persamaan Garis Lurus Ditinjau dari Karaketrisitik Cara Berpikir Siswa SMP Negeri Se-Kabupaten Pringsewu. Jurnal Elektronik Pembelajaran Matematika, 2(4), 411-421. 